\title{
Bark proportion of Scots pine industrial wood
}

\author{
Ferréol Berendt $^{1}$ (1) $\cdot$ Erik Pegel $^{1} \cdot$ Lubomir Blasko $^{2,3} \cdot$ Tobias Cremer $^{1}$
}

Received: 17 September 2020 / Accepted: 21 January 2021 / Published online: 9 February 2021

(c) The Author(s) 2021

\begin{abstract}
Bark characteristics are not only used in the forest-wood supply chain, for example to calculate standing volumes, but also to transform wood volumes and masses. In this study, bark thickness, bark volume and bark mass were analyzed on the basis of 150 Scots pine discs, with a mean diameter of $13 \mathrm{~cm}$. The mean double bark thickness was $3.02 \mathrm{~mm}$, the mean bark volume proportion was $5.6 \%$ and mean bark mass proportion was $3.3 \%$. Bark proportions were significantly affected by the log-specific variables 'diameter over bark', 'proportion of bark damage' and 'double bark thickness'.
\end{abstract}

\section{Introduction}

The concept of wood-based bioeconomy is gaining in importance and influences the management of forests for the purpose of reducing carbon emissions by providing both wood products and bioenergy. Additionally, new biomaterials made from wood and bark are becoming increasingly important for replacing fossil fuel based products, with steadily growing market segments. Bark, in particular, is very promising as its unique chemical composition allows for the production of various materials (Bauhus et al. 2017; Jansone et al. 2017). To date, bark has often been considered as a by-product or as a waste product from the industry. Moreover, there is a real need to quantify the bark thickness of common tree species given that currently used bark thickness estimations are old. Recent studies show that bark thickness tends to be thinner than bark deduction values, which in turn means that under-bark volume estimations are biased (Stängle and Dormann 2018). Additionally, precise and accurate estimations of bark volume, dry bark mass and bark damage are important values for the wood-based board

Ferréol Berendt

ferreol.berendt@hnee.de

1 Department of Forest Utilization and Timber Markets, Eberswalde University for Sustainable Development, 16225 Eberswalde, Germany

2 Landeswaldoberförsterei Chorin, Landesbetrieb Forst Brandenburg, 16225 Eberswalde, Germany

3 Department of Forest Harvesting, Logistics and Amelioration, Technical University Zvolen, 96001 Zvolen, Slovakia industry, as price negotiations are mostly based on stacked cubic meter or on dry mass and, as such, include the bark.

According to the national forest inventory $\left(\mathrm{BWI}^{3}\right)$, Scots pine (Pinus sylvestris, L.) is the most common tree species in northeastern Germany (federal states of Brandenburg and Berlin) and covers more than $70 \%$ of the forest area. Moreover, the wood of Scots pine has attractive properties for industrial utilization making this species one of the most commercially important tree species in Germany and Europe.

Therefore, the aims of this study were to quantify bark thickness, bark volume and bark mass of harvested Scots pine logs stacked at roadside. In doing so, it reflects typical seller-purchase negotiations occurring in the forest-wood supply chain.

\section{Materials and methods}

The dataset consisted of 50 logs, harvested during thinning operations, belonging to 10 different industrial wood piles which were dedicated to the board industry. The logs' origin was two different forest districts next to Eberswalde, in the federal state of Brandenburg. Site-specific data on the forests' trees such as age, diameter at breast height (DBH) and growth rate were obtained from the database of the forestry department. According to that database, the age of the Scots pine ranged from 47 to 107 years and DBH from 22 to $37 \mathrm{~cm}$. All $\operatorname{logs}$ were obtained from the upper part of the trees and, as no butt logs were included in the dataset, the bark of the 150 analyzed discs was thin and flaky. The approximately $4 \mathrm{~cm}$ thick discs were cut from the $3 \mathrm{~m}$ 
long logs at 30,150 and $270 \mathrm{~cm}$ starting from the large end. The mean diameter over bark $\left(\mathrm{d}_{\text {o.b. }}\right)$ of the discs was $12.9 \pm 2.1 \mathrm{~cm}$. As harvesting of Scots pine is usually highly mechanized, bark was partly damaged by harvester's rollers and/or delimbing knives during processing of the trees. The degree of bark damage was estimated with a measurement tape as the ratio of the disc circumference and the length of the bark damages. Double bark thickness (DBT) was calculated as the difference between $d_{\text {o.b. }}$ and the diameter under bark $\left(\mathrm{d}_{\mathrm{u} . \mathrm{b}}\right)$ of the wood discs. All diameters were measured with a precision caliper and calculated as the mean of two perpendicular measurements. The discs with known mass were immersed in a water bath and the displaced water mass (m) was determined in order to quantify the disc's volume (V) with $\mathrm{V}=\mathrm{m} / \rho_{\text {water }}$

Applied water density $\left(\rho_{\text {water }}\right)$ was between 0.9982 and 0.99754 as water temperature was between 20 and $23{ }^{\circ} \mathrm{C}$. The proportion of fresh bark volume $\left(\mathrm{V}_{\text {bark }}\right)$ was calculated as the difference between the disc's fresh volume over bark $\left(\mathrm{V}_{\text {o.b. }}\right)$ and under bark $\left(\mathrm{V}_{\text {u.b. }}\right)$ divided by $\mathrm{V}_{\text {o.b. }}$ :

$V_{\text {bark }}=\frac{V_{o . b .}-V_{u . b .}}{V_{o . b .}}$.

Moisture content of all $\operatorname{logs}$ except one, which was not further analyzed, was above fiber saturation point (MC $>30 \%$ ). Still, prior to volume and mass determination, all samples were soaked in water for $30 \mathrm{~min}$ to ensure no wood swelling during the measurements. Dry masses of both the wood $\left(\mathrm{m}_{\text {wood }}\right)$ and the bark $\left(\mathrm{m}_{\text {bark }}\right)$ were determined after drying the samples at $103 \pm 2{ }^{\circ} \mathrm{C}$ in a laboratory drying oven until constant weight was reached. The proportion of the dry bark mass $\left(\mathrm{M}_{\text {bark }}\right)$ was calculated as the ratio of $\mathrm{m}_{\text {bark }}$ and the sum of $\mathrm{m}_{\text {wood }}$ and $\mathrm{m}_{\text {bark }}$.

Regression analysis $(\alpha=0.05)$ was used to estimate the effect on three selected response variables: DBT, $\mathrm{V}_{\text {bark }}$ and $\mathrm{M}_{\text {bark}}$. The following independent variables were used in the linear regression: ' $\mathrm{d}_{\text {o.b. }}$, origin ('forest district', 'wood pile'), 'stand age', 'DBH', 'degree of bark damage' and 'growth rate'. Moreover, for the response variables $\mathrm{V}_{\text {bark }}$ and $\mathrm{M}_{\text {bark, }}$ the two additional independent variables 'degree of bark damage' and 'DBT' were used in the model.

\section{Results and discussion}

The mean DBT was $3.02 \pm 1.49 \mathrm{~mm}$ and, considering all analyzed discs, was not significantly affected by $\mathrm{d}_{\text {o.b. }}$. In relation to $\mathrm{d}_{\text {o.b. }}$, DBT had a proportion of $2.4 \pm 1.2 \%$. Only the independent variable 'forest district' was significant (Fig. 1). The significance of the forest district may be strongly influenced by one wood pile that showed significantly higher DBTs. On the site of that wood pile, oaks were the dominant

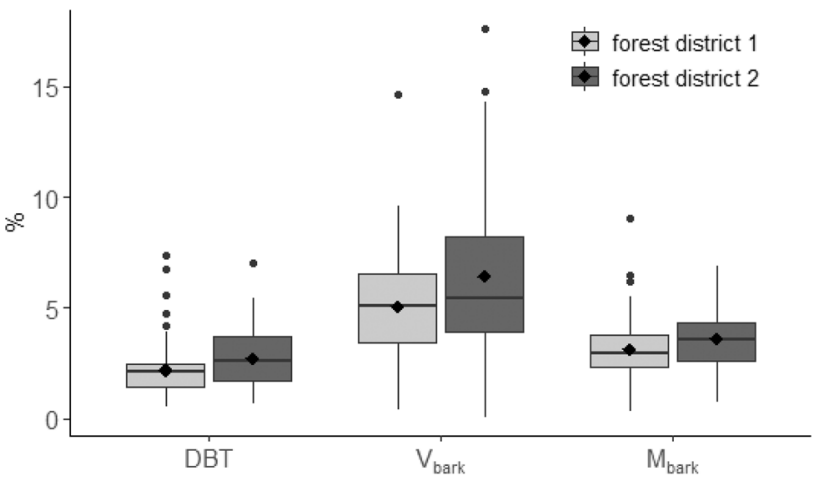

Fig. 1 Bark characteristics of Scots pine. DBT as the ratio of the double bark thickness to $d_{\text {o.b. }}, M_{\text {bark }}$ as the ratio of dry bark mass to dry disc' mass, $V_{\text {bark }}$ as the ratio of fresh bark volume to fresh disc volume

tree species with a proportion of $73 \%$. On all other sites, Scots pine was either growing as monoculture or as the dominant tree species with other tree species in understory. The significance of the forest district should not be generalized as also shown for European silver fir in southern Germany: geographic coordinates, elevation, temperature and precipitation did not have a significant influence on the variation of bark thickness (Stängle and Dormann 2018). Compared with a study from the Czech Republic, the findings of this study show lower DBT. There, to estimate under bark volume of Scots pine, DBT values of $4.14 \mathrm{~mm}$ and $5.71 \mathrm{~mm}$ for logs with diameters from 8 to $15 \mathrm{~cm}$ and from 15 to $22 \mathrm{~cm}$, respectively, are used (Natov and Dvořák 2018 as cited in Sedmíková et al. 2020). Higher DBTs may result either from trees where the bark is changing from thin and flaky to thick, rough and scaly, or from different growing conditions (e.g. natural regenerations vs. planted trees). Thus, the effect of mixing tree species on the DBT should be further investigated, as the low sample size does not allow for generalization.

With increasing $d_{\text {o.b. }}$ or increasing bark damage, $V_{\text {bark }}$ (defined as the proportion of bark in relation to the disc's volume) decreased significantly; and vice versa, $\mathrm{V}_{\text {bark }}$ was positively influenced by increasing DBT. None of the other variables significantly affected $\mathrm{V}_{\text {bark. }}$. In relation to the discs' volume, the bark had a mean volume of 5.1 and $6.4 \%$ for forest districts 1 and 2, respectively (Fig. 1). The mean $\mathrm{V}_{\text {bark }}$ was $5.6 \pm 3.1 \%$, which is lower than findings from Latvia for relative tree height between 40 and $60 \%$ with $\mathrm{V}_{\text {bark }}$ of approximately 8.2\% (Liepins and Liepins 2015). Another study estimated volumetric bark proportion for Scots pine industrial wood in Germany and Switzerland and reported a mean value of $9.1 \%$ (Dietz 1975). As the aim of this study was to estimate bark proportion of logs delivered to mills, the non-negligible bark damage of $12.0 \pm 14.8 \%$ should be added for comparability reasons. The lower bark proportions 


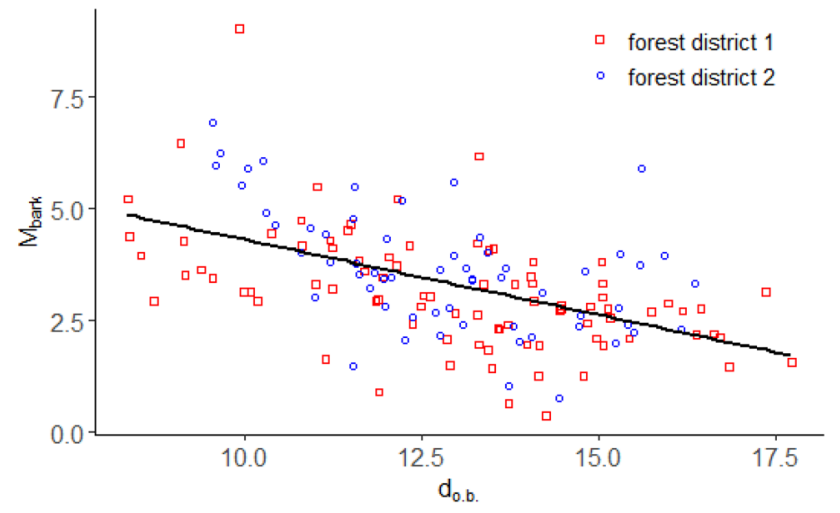

Fig. $2 \mathrm{M}_{\text {bark }}$ (in \%) in relation to $\mathrm{d}_{\text {o.b. }}$ (in $\mathrm{cm}$ ) considering the two forest districts

compared to findings from other studies may further be explained by the examined wood assortments of small diameter Scots pine logs, which all had the thin, flaky and red-orange bark. For Scots pine, such a bark form is typical for the upper trunk, which is often used as industrial wood, whereas the wood of the lower trunk, with thick bark, is mostly designated to sawmills. Most studies have not considered the bark form, and, thus, their results are highly variable (Dietz 1975). Moreover, the bark form and bark proportion may change over the tree height and lowest values are found between 30 and $60 \%$ relative height for Scots pine (Liepins and Liepins 2015).

Mean $\mathrm{M}_{\text {bark }}$ was $3.3 \pm 1.4 \%$ (with 3.1 and 3.6\% for forest districts 1 and 2, respectively, see Fig. 1) and, thus, lower than the findings of Dietz for German conditions with 6.3\% (Dietz 1975). Dietz followed a similar aim, which was to find the wood-bark ratio for both volume and mass in order to provide the wood industry with an overview of bark amount when purchasing a given amount of wood. However, in the 1970s, timber harvesting was not fully mechanized and, therefore, bark damage most probably had no effect on bark proportion. The model of $\mathrm{V}_{\text {bark }}$ had a coefficient of determination $\left(\mathrm{R}^{2}\right)$ of 0.30 , whereas the model of $\mathrm{M}_{\text {bark }}$ showed $a R^{2}$ of 0.52 when considering the significant independent variables ' $\mathrm{d}_{\text {o.b. }}$,' 'DBT' and 'bark damage' (Fig. 2).

Using wood discs instead of whole logs was found to be highly advantageous and is recommended for further investigations related to accurate measurements of BDT, $\mathrm{V}_{\text {bark }}$ and $\mathrm{M}_{\text {bark }}$ under laboratory conditions. Measurements were taken under laboratory conditions and the true volume of the discs was quantified with xylometry (water immersion technique). Therefore, no formulae or calculations for estimation of volumes had to be used. Still, such measurement techniques cannot be applied during forest operations to check or control DBT or bark volume on selected logs. However, for Scots pine tree compartments with thin bark, measurement of DBT can neither be done with usual bark gauges nor with a forestry caliper, as this would not be sufficiently precise. Further analyses of bark proportions with the described methodologies will provide the opportunity to accurately quantify DBT, $\mathrm{V}_{\text {bark }}$ and $\mathrm{M}_{\text {bark }}$ in order to revise estimation models, which are needed by both practical forestry companies and wood processing industries.

\section{Conclusion}

The findings regarding DBT, bark volume and bark mass should be further investigated and extended to cover different forest areas, and butt logs with differing bark proportions should also be included. For Scots pine industrial wood with thin bark, DBT is small and therefore measurements should be as precise as possible. Economically, differences of a few millimeters, which easily occur as measuring errors, may have huge financial impacts for a forestry or wood processing company. Thus, to be able to estimate correct bark proportion in industrial wood stacks, the database should be increased in order to validate DBT, $\mathrm{V}_{\text {bark }}$ and $\mathrm{M}_{\text {bark }}$. Therewith, current correction and conversion factors could be defined for both the forest and the wood industry.

Acknowledgements The authors want to thank the Landeswaldoberförsterei Chorin for the provision and transport of the logs as well as Fabio Zölch for technical support.

Author contributions FB, TC and LB conceived and designed the experiments; FB, EP performed the experiments; FB and EP analyzed the data; FB wrote the paper with contributions from TC, EP and LB.

Funding Open Access funding was enabled and organized by Projekt DEAL. This study was undertaken in the framework of the project "HoBeOpt", which was financially supported via the Fachagentur Nachwachsende Rohstoffe (FNR), Germany, by the Federal Ministry of Food and Agriculture (BMEL) (Grant number: 22007918).

Availability of data and material The datasets analyzed during this study are available from the corresponding author on reasonable request.

\section{Compliance with ethical standards}

Conflict of interest The authors declare that they have no conflict of interest.

Open Access This article is licensed under a Creative Commons Attribution 4.0 International License, which permits use, sharing, adaptation, distribution and reproduction in any medium or format, as long as you give appropriate credit to the original author(s) and the source, provide a link to the Creative Commons licence, and indicate if changes were made. The images or other third party material in this article are included in the article's Creative Commons licence, unless indicated otherwise in a credit line to the material. If material is not included in the article's Creative Commons licence and your intended use is not permitted by statutory regulation or exceeds the permitted use, you will 
need to obtain permission directly from the copyright holder. To view a copy of this licence, visit http://creativecommons.org/licenses/by/4.0/.

\section{References}

Bauhus J, Kouki J, Verkerk PJ (2017) How does the forest-based bioeconomy impact forest biodiversity? In: Winkel G (ed) Towards a sustainable European forest-based bioeconomy. Assessment and the way forward. European Forest Institute (What science can tell us, 8), Joensuu, pp 67-76

Dietz P (1975) Dichte und Rindengehalt von Industrieholz (Density and bark content of industrial raw wood). Holz Roh-Werkst 33(4):135-141. https://doi.org/10.1007/BF02611237.

Jansone Z, Muizniece I, Blumberga D (2017) Analysis of wood bark use opportunities. Energy Procedia 128:268-274. https://doi. org/10.1016/j.egypro.2017.09.070
Liepins J, Liepins K (2015) Evaluation of bark volume of four tree species in Latvia. Res Rural Dev 2:22-28

Natov P, Dvořák J (2018) Doporučená pravidla pro elektronický př́ijem dříví harvestory v ČR 2018. 1. vydání. Praha: Produkce BPP s.r.o. ISBN: 978-80-906874-7-9

Sedmíková M, Löwe R, Jankovský M, Natov P, Linda R, Dvořák J (2020) Estimation of over- and under-bark volume of scots pine timber produced by harvesters. Forests 11(6):626. https://doi. org/10.3390/f11060626

Stängle SM, Dormann CF (2018) Modelling the variation of bark thickness within and between European silver fir (Abiesalba Mill.) trees in southwest Germany. Forestry 91(3):283-294. https://doi. org/10.1093/forestry/cpx047

Publisher's Note Springer Nature remains neutral with regard to jurisdictional claims in published maps and institutional affiliations. 